\title{
新指標“花成強度”を用いたダイコンの春化中の高温による 離春化程度の明確化
}

\author{
$千$ 春 鎮・斎藤 隆 \\ 東京農業大学農学部
}

\begin{abstract}
An Approach to the Characterization of Devernalization due to High Temperature Interruption during Vernalization in Radish Plants Using

"Flower Formation Index"

Chun-jin ChEON and Takashi SAITO

Faculty of Agriculture, Tokyo University of Agriculture, Atsugi, Kanagawa 243-0034, Japan
\end{abstract}

(Received April 8, 2003)

\begin{abstract}
Plants of radish 'Taibyo-sohbutori' were exposed to the low temperature treatment $\left(6^{\circ} \mathrm{C}\right)$ with an interruption of high temperature $\left(17,24\right.$ or $\left.30^{\circ} \mathrm{C}\right)$ for 4,6 or $8 \mathrm{hr}$ per day, respectively. We applied a new index "flower formation index" to the data of floral induction after the treatment in order to estimate hours per day contribute to devernalization and vernalization. According to "flower formation index", the inflorescence formation suppressed under the high temperature treatment at $24^{\circ} \mathrm{C}$ for 6 to $8 \mathrm{hr}$ per day, and this suppression markedly occurred at higher temperature of $30^{\circ} \mathrm{C}$. In the case of intermittent low temperature treatment, by calculating "estimated hours per day contribute to vernalization and devernalization", it was possible to recognize the effect of high temperature interruption during low temperature treatment. We supposed that the vernalization effect by a low temperature treatment would be counteracted by $30-40 \%$, if the plants are exposed to $24^{\circ} \mathrm{C}$ for $8 \mathrm{hr}$ or $30^{\circ} \mathrm{C}$ for $6 \mathrm{hrs}$ per day during the low temperature treatment.
\end{abstract}

Keywords : flower formation index, Raphanus sativus L., vernalization, devernalization

2003 年 4 月 8 日受付

\section{$\therefore$ 緒}

低温感応性の葉・根菜類の春播き栽培などにおいて, 低温に遭遇する恐れのある場合, トンネル被覆などに よって日中高温に保つことで, 夜間の低温遭遇による 春化作用が打ち消される，いわゆる離春化を起こして 花芽形成が抑制され，抽だいが軽減，防止できること が認められている(ダイコン：Kagawa and Nakamura, 1958 ; Sato et al., 1980 ; Suzuki et al., 1980 ; Seyama and Takai, 1982 ; Kodo et al., 1983 ; Sagwansupyakorn et al., 1984 ; Kodo et al., 1985; Kitada et al., 1988 ; Matsubara et al., 1990, ニンジンやセルリー： Moriwaki and Katsumata, 1974 ; Moriwaki et al., 1975 ; Moriwaki et al., 1976; Moriwaki and Yamaguchi, 1977, キャベツ：Ito and Saito, 1961)。これらの報告では主 として抽だい状態を調査し，トンネル被覆や昼・夜間 の変温処理などによって日中を高温に保つことで抽だ いが遅れ，抽だい率が低下したことなどが認められて いるが，低温感応および低温感応の消去の詳細につい ては明らかにされていない。

低温感応性の葉・根菜類において，春化の上限の温

Corresponding author : Chun-jin Cheon, fax : +81-29-855-3699, e-mail : chunjin58@ hotmail.com 
度と離春化の下限の温度を明確にすることは, 高温に よる抽だい防止効果を推測する上で極めて重要であ る. Saito and Saito (2003) は，カブについて, “花成 強度”という新しい指標を用いて春化および離春化の 程度を定量的に把握している。

本研究では, “花成強度”という新しい指標を用いて, ダイコンの低温感応に対する低温処理中の高温作用に ついて，高温の段階と処理期間を組み合わせて断続低 温処理を行い, 連続低温処理と対比して春化（低温感 応）および離春化（低温感応の消去）の作用を定量的 に把握することを試みた。

\section{材料および方法}

\section{供試材 料}

材料には, ダイコン (Raphanus sativus L.) ‘耐病 総太り’（タキイ種苗）を供試した。温度処理終了日を 同一にするため 1999 年 3 月 8 日から 5 月 2 日に, 催芽 種子を園芸培養土 (呉羽化学 (株)) を詰めた直径 $9 \mathrm{~cm}$ のポットに播種した. 播種直後に昼温 $25^{\circ} \mathrm{C}$, 夜温 $20^{\circ} \mathrm{C}$, 日長 12 時間 (白色蛍光灯, $230 \mu \mathrm{mol} \mathrm{m}^{-2} \mathrm{~s}^{-1}$ PPFD) の人工気象器 (日本医化 (株), BIOTORON LH-200 型）内に搬入し，子葉展開時まで育成した。

\section{連続低温処理と断続低温処理}

低温処理区としては, 低温処理を連続して行う連続 低温処理区と低温処理期間中の日中に高温処理を行う 断続低温処理区を設けた. 低温処理温度は $6^{\circ} \mathrm{C}$ とし, 高温処理温度は 17,24 および $30^{\circ} \mathrm{C}$ の 3 段階とした。 連続低温処理区では, 低温処理の積算時間を 480 時間 (20日間)，720 時間 (30日間)，960 時間 (40日間) お よび 1200 時間 (50 日間) とした。断続低温処理区では, $6{ }^{\circ} \mathrm{C}$ での低温処理中に，高温処理を 1 日当たり 4 時間 $(8: 00 \sim 12: 00), 6$ 時間 $(8: 00 \sim 14: 00)$ および 8 時 間 $(8: 00 \sim 16: 00)$ 行う処理区を設け, さらに, 低温 処理の積算時間を連続低温処理と同様に 480 時間 (20 日間相当), 720 時間 (30 日間相当), 960 時間 (40 日 間相当）および 1200 時間 (50 日間相当) として, これ らを組み合わせ計 36 区を設けた， 1 処理区当たり 12 株を供試した。

温度処理は, 人工気象器内で 8 時間の日長 (白色蛍 光灯, $55 \mu \mathrm{mol} \mathrm{m}^{-2} \mathrm{~s}^{-1}$ PPFD) 下で行った. 温度処理 は, 各播種後 4 日目の 3 月 11 日から 5 月 5 日に, 子葉 が完全に展開してから開始し, 処理開始から 20〜75 日 後の 5 月 25 日に一斉に終了した.

\section{温度処理終了後の調查}

温度処理終了後の 5 月 25 日に自然光ガラス室内に 移し, 25 日間育成した.温度処理終了 25 日後の 6 月 19 日に一斉に株を採取し, 頂花房の形成株率, 頂花房ま での節数 (着花節位), 側花房の形成節数について実体 顕微鏡を用いて調べた.これらの結果から Saito and Saito (2001) が考案した“花成強度”を下式により求 めた。

$$
\begin{aligned}
\text { 花成強度 }(\%)= & \text { 頂花房の形成株率 }(\%) \\
& \times \frac{\text { 頁花房節 }+ \text { 側花房の形成節数 }}{\text { 頂芽節 }+ \text { 頂花房までの節数 }}
\end{aligned}
$$

\section{結果}

\section{1. 頂花房の形成株率}

低温処理による頂花房の形成株率を Fig. 1 に示し た.

連続低温処理区では, 最も短い 480 時間低温処理で すでに全株で頂花房の形成がみられた。

断続低温処理区における $17^{\circ} \mathrm{C}$ 区では, 1 日当たり 4, 6 および 8 時間のいずれの高温処理でも，480 時間

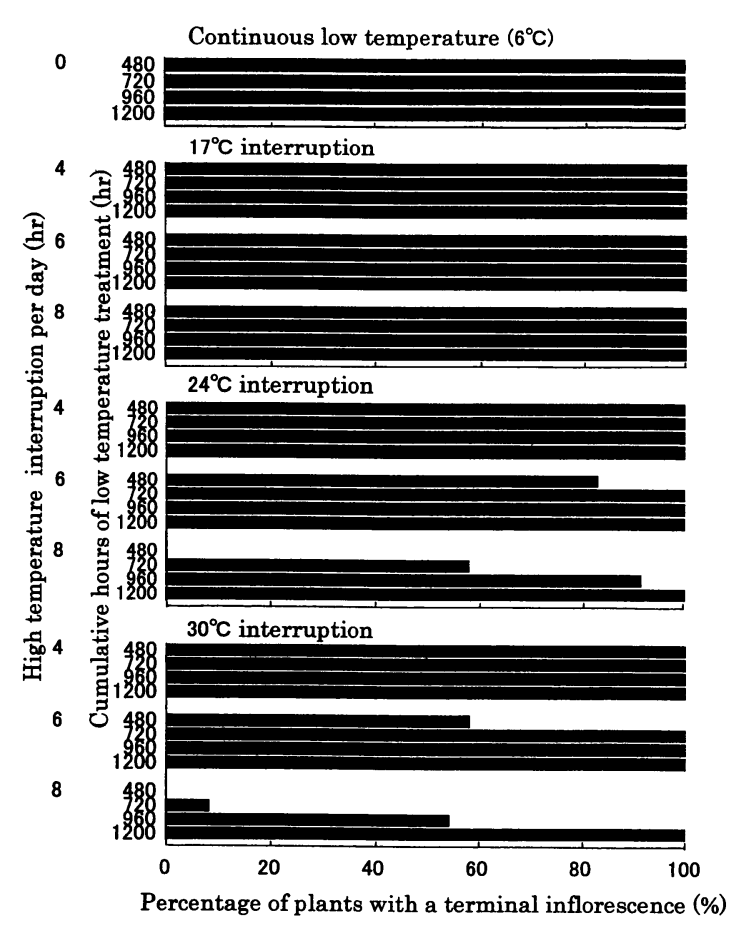

Fig. 1 Effects of high temperature interruption during low temperature treatment on the percentage of plants with a terminal inflorescence in radish 'Taibyo-sohbutori'.

生物環境調節 (Environ. Control in Biol.) 
低温処理ですでに全株で頂花房の形成がみられ，連続 低温処理区と全く同様であった， $24^{\circ} \mathrm{C}$ 区では，1 日当 たり 4 時間の高温処理の場合，480 時間低温処理で頂 花房の形成が全株でみられたが，6時間の高温処理で は, 頂花房の形成株率は $83 \%$ とやや低下した. しかし, 720 時間以上の低温処理では全株で頂花房の形成がみ られた. 1 日当たり 8 時間の高温処理の場合, 480 時間 低温処理では頂花房の形成は全くみられず，720 時間 低温処理で $58 \%, 960$ 時間低温処理で $92 \%$ と, 連続低温 処理区に比べて頂花房の形成株率は低下し，1200 時間 低温処理では全株で頂花房の形成がみられた. $30^{\circ} \mathrm{C}$ 区 では, 1 日当たり 4 および 6 時間の高温処理の場合, 頂 花房の形成株率は $24^{\circ} \mathrm{C}$ 区とほほ同様な傾向を示した が, 8 時間の高温処理の場合, 頂花房の形成は強く抑制 され，720 時間処理までは頂花房の形成はほとんどみ られず, 960 時間処理で 55\%, 1200 時間低温処理では全 株で頂花房の形成がみられた。

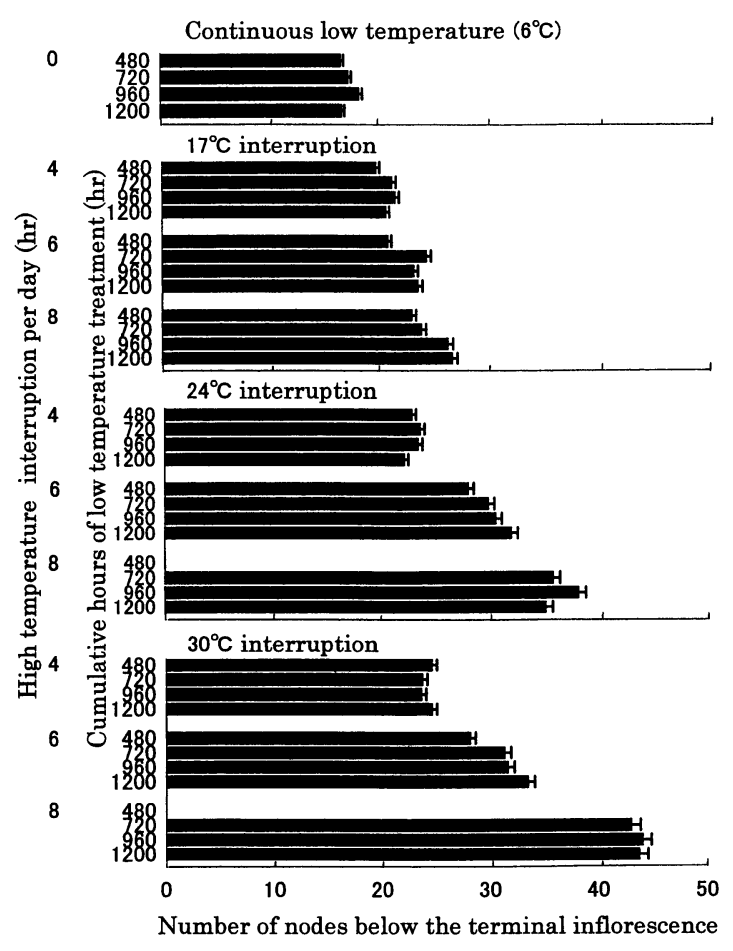

Fig. 2 Effects of high temperature interruption during low temperature treatment on the number of nodes below the terminal inflorescence in radish 'Taibyo-sohbutori'. Horizontal bars represent SE.

Vol. 41, No. 4 (2003)

\section{2. 着 花節 位}

低温処理による着花節位を Fig. 2 に示した。

連続低温処理区における着花節位は，いずれの低温 処理時間でも $17 〜 18$ 節であった。

断続低温処理区における着花節位は，連続低温処理 区に比べて著しく上昇し，高温処理温度が高いほど, 1 日当たりの高温処理時間が長いほど上昇した。例え ば 1 日当たり 8 時間の高温処理区における着花節位 は, $17^{\circ} \mathrm{C}$ 区の $23 \sim 27$ 節, $24^{\circ} \mathrm{C}$ 区の $36 \sim 39$ 節, $30^{\circ} \mathrm{C}$ 区 の 43〜 44 節と上昇した.

\section{3. 側花房の形成節数}

低温処理による側花房の形成節数を Fig. 3 に示し た.

連続低温処理区における側花房の形成節数は，いず れの低温処理時間でも 14 節前後となり,低温処理時間 による差はほとんどみられなかった。

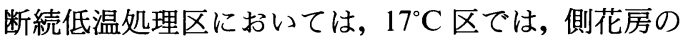
形成節数は，いずれの高温処理時間でも 480 時間低温

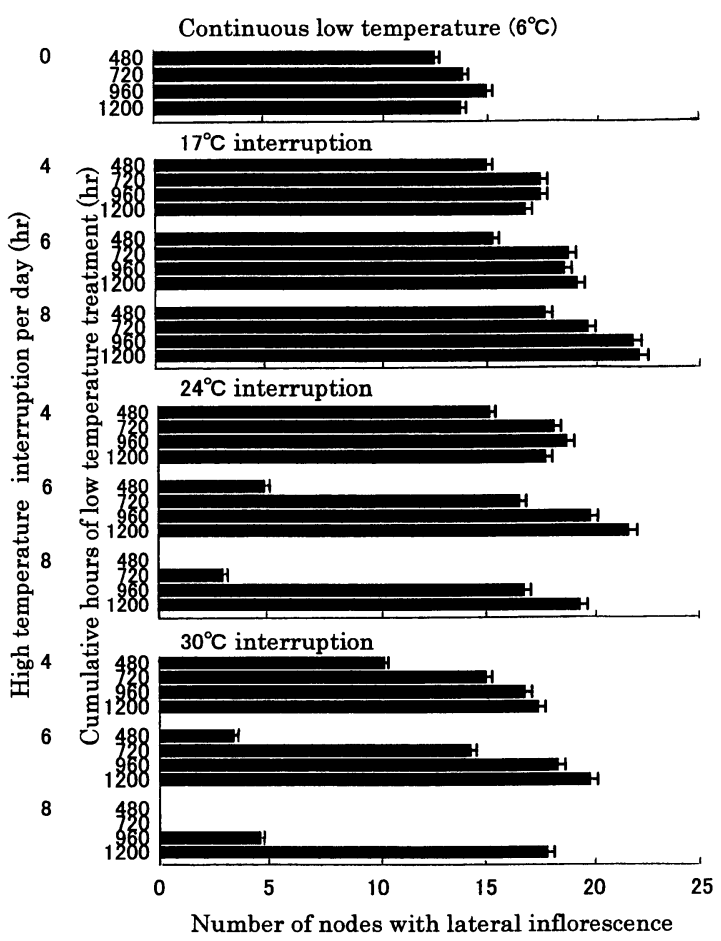

Fig. 3 Effects of high temperature interruption during low temperature treatment on the number of nodes with lateral inflorescence in radish 'Taibyo-sohbutori'. Horizontal bars represent SE. 
処理で少ないが，720 時間以上では低温処理時間によ る差は少なく，1 日当たり 4 時間高温処理では $17 \sim 18$ 節, 6 時間高温処理では 19〜20 節，8 時間高温処理で は20〜22 節で, 1 日当たりの高温処理時間が長いほど 増加した. 24 および $30^{\circ} \mathrm{C}$ 区では，側花房の形成節数 は, 高温処理の温度が高く, また, 1 日当たりの高温処 理時間が長く，低温処理時間が短い場合は減少し，30 ${ }^{\circ} \mathrm{C}$ 区の 8 時間高温処理では，720 時間低温処理までは ほとんどみられなかったが, 1200 時間低温処理では増 加した。

\section{4. 花成強度}

低温処理による花成強度を Fig. 4 に示した。

連続低温処理区における花成強度は, 低温処理 480 時間で $79 \%, 720$ 時間で $83 \%, 960$ 時間で 84\%，1200 時 間で $85 \%$ と，低温処理時間が多いほど高くなる傾向を

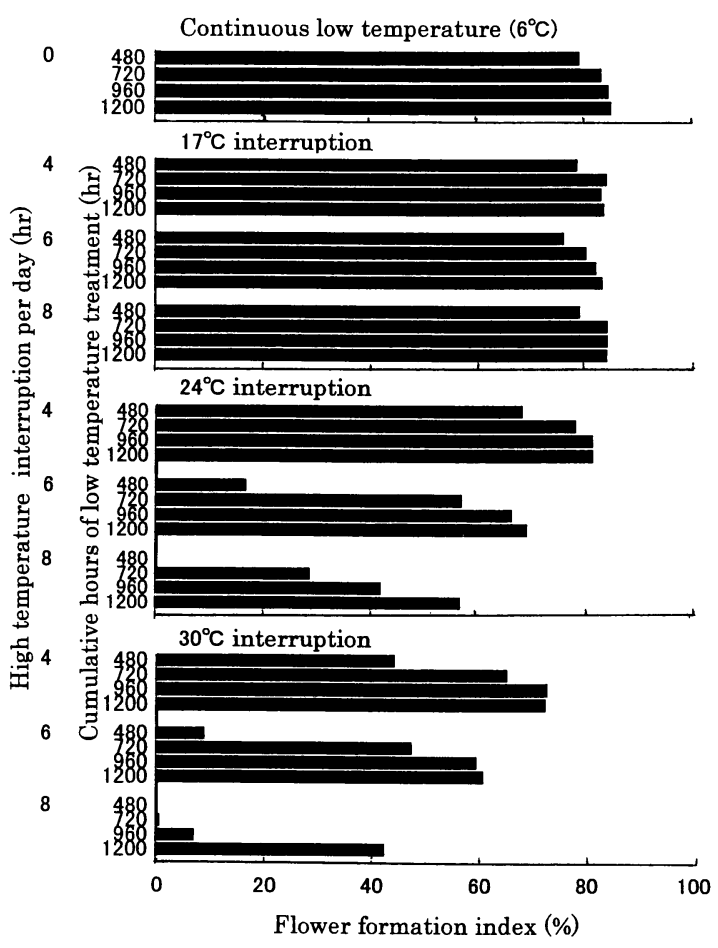

Fig. 4 Effects of high temperature interruption during low temperature treatment on the flower formation index in radish 'Taibyo-sohbutori'. Flower formation index $=$ Percentage of plants with a terminal inflorescence $\times$ (Node of terminal inflorescence + Number of nodes with lateral inflorescence)/(Node of terminal bud + Number of nodes below the terminal inflorescence).
示した。

断続低温処理区においては，170 区では，花成強度 は， 1 日当たり 4,6 および 8 時間のいずれの高温処理 時間でも連続低温処理区とほほ同じ值を示し, 断続処 理の影響はみられなかった。 24 および $30^{\circ} \mathrm{C}$ 区では, 花 成強度は, 高温処理温度が高いほど, 1 日当たりの高温 処理時間が長いほど順次低下し, $30^{\circ} \mathrm{C}$ の 1 日当たり 8 時間処理区で最も低かった。

\section{考察}

\section{花房形成に及ぼす低温処理中の高温の影響}

ダイコンの頂花房および側花房における花房形成 は, 低温処理の積算時間が同一でも, 連続低温処理に 比べて断続低温処理で抑制され，高温処理の温度が高 いほど,また, 1 日当たりの高温処理時間が長いほど強 く抑制された.低温処理中の高温処理温度については, $17^{\circ} \mathrm{C}$ では，頂花房の形成株率はまったく低下しなかっ たが，着花節位はかなり上昇しており，頂花房の分化 時期が遅れたものとみられ，高温に処理された時間だ け連続低温処理に比べて低温処理の積算時間に達する 時期が遅れ，その間に主茎の分化葉数が増加したため と考えられた。側花房の形成節数は 1 日当たりの高温 処理時間が長いほど増加しており, 高温処理時間だけ 低温処理期間が長くなっており, 頂花房形成後の低温 感応は連続低温処理区に比べて長く続いたものと考え られた。しかし, 花成強度は $80 \%$ 前後といずれの高温 処理時間でも連続低温処理と同様であり, $17^{\circ} \mathrm{C}$ の高温 処理による断続低温処理では連続低温処理と比べて花 房形成の抑制作用も助長作用もなかったものと考えら れた. 低温処理中の $24^{\circ} \mathrm{C}$ 以上の高温処理による断続 低温処理では, 高温処理温度が高いほど, また, 1 日当 たりの高温処理時間が長いほど, 頂花房の形成は抑制 され，着花節位は著しく上昇し，側花房の形成節数は 低温処理時間の少ない場合は減少し, 低温処理時間の 多い場合は増加したが, 花成強度は順次低下し, 花房 形成は著しく抑制されたものと考えられた。これまで にも, Seyama and Takai (1982) は, ダイコン 10 品 種を用いて, $5^{\circ} \mathrm{C} て ゙ の$ 低温中に $15,22.5$ および $30^{\circ} \mathrm{C}$ の 各高温に 1 日当たり 6 時間処理した場合, $15^{\circ} \mathrm{C}$ では低 温作用の打ち消しは全くみられず，逆に抽だいが促進

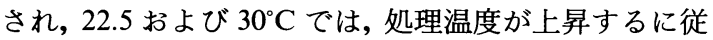
い低温の作用が抑制され，抽だい率が低下したことを 認めている. Sagwansupyakorn et al. (1984) は, ダイ コン ‘みの早生’について, 夜間 12 時間を $5^{\circ} \mathrm{C}$ とし, 昼 
間 12 時間を 14,17 および $20^{\circ} \mathrm{C}$ と変温処理を行った 場合, $17^{\circ} \mathrm{C}$ では $14^{\circ} \mathrm{C}$ に比べて花芽分化期は若干遅れ たものの全株で花芽分化したが, $20^{\circ} \mathrm{C}$ では花芽形成が 著しく低下したことを報告している. Kitada et al. (1988) は, ダイコン“耐病総太り’について, 夜間 12 時 間を $5^{\circ} \mathrm{C}$ とし, 昼間 12 時間を 15,19 および $23^{\circ} \mathrm{C}$ と変 温処理を行った場合, 昼温 $19^{\circ} \mathrm{C}$ 以上で離春化作用が 強く現れたことを認めた。しかし, 春化の上限温度と 離春化の下限温度は未だに明瞭にされていない。

ダイコンの花房形成における春化（低温感応）の上 限温度について, 著者らは前報 (Watanabe et al., 2003)


十分に起こったことから, 花房形成の低温の上限温度 は $15^{\circ} \mathrm{C}$ 以上であるように推定した。本実験において さらに, $17^{\circ} \mathrm{C}$ ではまったく低温感応の作用が助長も抑 制もされなかったことから, 春化の上限の温度は 15 $16^{\circ} \mathrm{C}$ であり, 離春化の下限の温度は $18 \sim 19^{\circ} \mathrm{C}$ である と考えられた。このように, 低温感応性の葉・根菜類 において, 春化の上限の温度と離春化の下限の温度を 明確にすることは，高温による抽だい防止効果を推測 する上で極めて重要である.

\section{春化作用の累穔と離春化の程度を推定する新しい指 標}

“花成強度”を用いると, 頂花房の形成株率, 着花 節位および側花房の形成節数という指標を単独で用い て明瞭な差がみられなかった場合でも，花房形成に及 ほすす低温処理中の高温処理の影響を定量的に表すこと ができた. Saito and Saito (2003) は，カブひひかり’に
ついて, “花成強度”を用いて, 断続低温処理作用を春 化作用累積時間として計算し, 春化作用の累積と離春 化の程度を推定した。 そこで, 本報でもダイコンにつ いて, “花成強度”を用いて, 断続低温処理を行った場 合の春化作用累積時間を求め, 離春化の程度を推定し た。

（1）「春化作用累積時間」の推定

連続低温処理の場合, 春化作用の累積は低温処理の 積算時間として表され，その花房形成状態を “花成強 度”で定量的に表すことが可能であった。 そこで，「断 続低温処理区の春化作用累積時間」は, 「断続低温処理 区の花成強度」を「連続低温処理区の花成強度」で除 し，低温処理積算時間を乗じて推定した（Fig. 5).

断続低温処理区の春化作用累積時間 $=$ 低温処理積算時間 $\times \frac{\text { 断続低温処理区の花成強度 }}{\text { 連続低温処理区の花成強度 }}$

その結果, “花成強度”で表されている花房形成の状 態を春化作用の累積状態として直接表すことができ, $17^{\circ} \mathrm{C}$ 区で連続低温処理区とほほ同様に累積され, $24^{\circ} \mathrm{C}$ 以上の区では, 高温処理温度が高いほど, また, 1 日当 たりの高温処理時間が長いほど春化作用の累積が少な くなることが示された。

（2）「1 日当たりの春化作用時間」および「1日当た りの離春化作用時間」

次に，「春化作用累積時間」を「低温処理日数」で除 し，「1 日当たりの春化作用時間」を求め,さらに，「1 日当たりの低温処理時間」から「1 日当たりの春化作用 時間」を差し引き，「1 日当たりの離春化作用時間」を

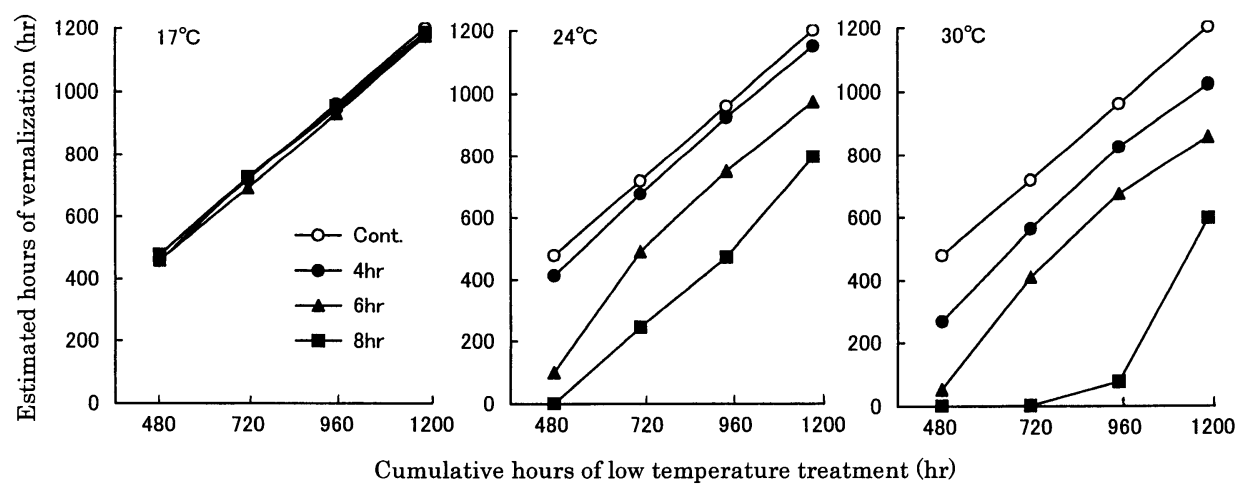

Fig. 5 Effects of high temperature interruption during low temperature treatment on the relation between cumulative hours of low temperature and estimated hours of vernalization in radish 'Taibyo-sohbutori'. Cont ; Continuous low temperature treatment at $6^{\circ} \mathrm{C}$. Estimated hours of vernalization $(\mathrm{hr})=$ Cumulative hours of low temperature $\times$ Flower formation index of high temperature interruption during low temperature treatment/Flower formation index of continuous low temperature treatment.

Vol. 41, No. 4 (2003) 


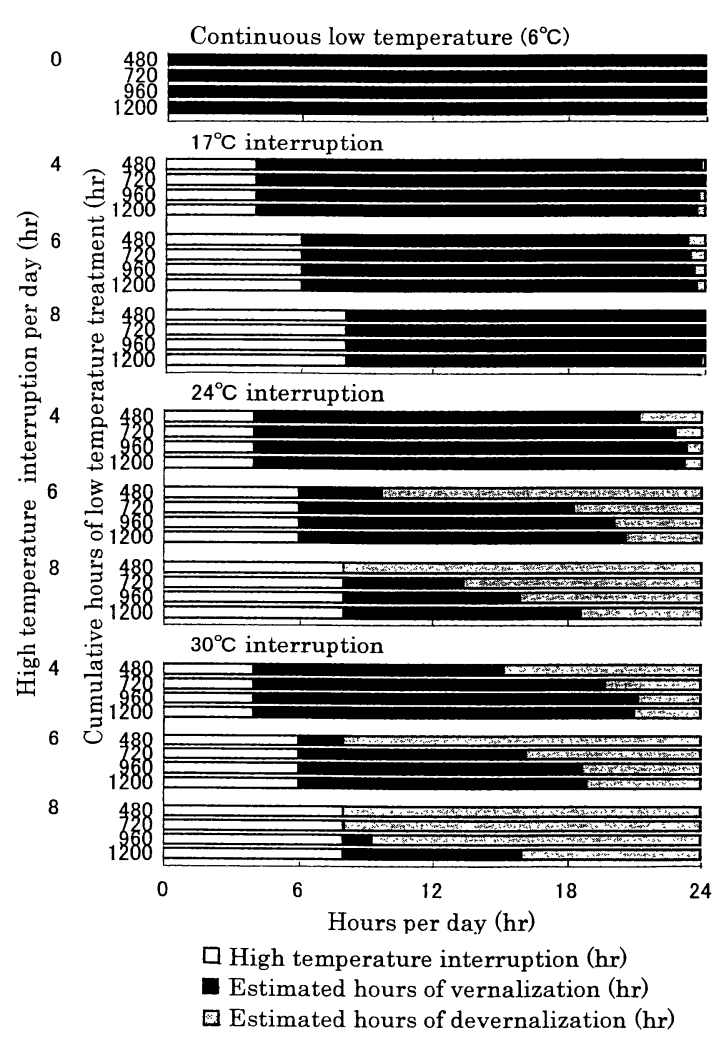

Fig. 6 Effects of high temperature interruption during low temperature treatment on the estimated hours of vernalization and devernalization per day in radish 'Taibyo-sohbutori'.

求めた (Fig. 6).

$17^{\circ} \mathrm{C}$ 区では，1 日当たり 4,6 および 8 時間のいずれ の高温処理時間を行っても, 低温処理の積算時間にか かわらず春化に作用し, 離春化はほとんど起こらない と推定され，断続低温処理でも連続低温処理とほほ同 様であると考えられた。

$24^{\circ} \mathrm{C}$ 区では，1 日当たり 4 時間の高温処理を行う と, 低温処理の積算時間が 480 時間の場合, 低温処理 時間 20 時間のうち $86 \%$ が春化に作用し， $14 \%$ が離春 化されたが, 低温処理時間が長くなると春化作用が強 まり, 1200 時間の場合, 低温処理時間 20 時間のうち 98\%のほとんどが春化に作用し, $2 \%$ のごくわずかが離 春化されるとみられた。しかし, 1 日当たり 6 時間の高 温処理を行うと, 春化の作用が弱まり, 低温処理の積 算時間が 960〜 1200 時間の場合, 低温処理時間 18 時間 のうち 78〜81\% が春化に作用し，22〜19\% が離春化さ れるとみられた.また, 1 日当たり 8 時間の高温処理を
行うと, 春化の作用はさらに弱まり, 低温処理の積算 時間が 960 1200 時間の場合, 低温処理時間 16 時間の うち 49〜 66\% 程度が春化に作用し，51〜34\% 程度が離 春化されるとみられた。このように $24^{\circ} \mathrm{C}$ 区では $17^{\circ} \mathrm{C}$ 区に比べて春化の程度が弱く, 離春化の程度が大きく なり, 1 日当たり 8 時間の高温処理では春化作用の $40 \%$ 以上が打ち消されるものと推定された。

$30^{\circ} \mathrm{C}$ 区では，1 日当たり 4 時間の高温処理を行う と, 低温処理の積算時間が 960〜 1200 時間でも, 低温 処理時間 20 時間のうち 85〜 86\% が春化に作用し, 14〜15\%が離春化されるとみられた. 1 日当たり 6 時 間の高温処理を行うと, 春化の作用はさらに弱まり, 低温処理の積算時間が 960 1200 時間の場合, 低温処 理時間 18 時間のうち $70 〜 71 \%$ 程度が春化に作用し, $30 \sim 29 \%$ 程度が離春化されるとみられた。 1 日当たり 8 時間の高温処理を行うと, 低温処理の積算時間が 720 時間まではほとんど離春化され, 960 時間でも $8 \%$ のみ が春化に作用し, 92\%が離春化され，1200 時間では $48 \%$ が春化に作用し, $52 \%$ が離春化され, 春化の作用は 著しく弱くなり, 離春化の作用は極めて大きくなると みられた.このように, $30^{\circ} \mathrm{C}$ 区では $24^{\circ} \mathrm{C}$ 区に比べて離 春化の程度は大きく, さらに高温処理時間が長いほど その差は大きくなるものと推定された.

以上のように, 1 日当たりの春化作用時間と離春化 作用時間を求めることで, 24 時間のうち春化に作用し た時間と離春化された時間の収支を明確にすることが でき，低温遭遇中の高温の影響を実用的な形で把握す ることが可能になると考えられる。

\section{摘 要}

新指標 “花成強度”を用いてダイコンの離春化程度 を明確にするため, 花房形成に対する低温処理中の高 温処理の影響について検討した. ‘耐病総太り’の幼苗 を $6^{\circ} \mathrm{C}$ で低温処理中に, 17,24 および $30^{\circ} \mathrm{C}$ の高温に, 1 日当たり 4,6 および 8 時間遭遇させる断続低温処理 を行った. 温度処理終了後, 花成の様相を調べ, “花成 強度”を求めた.さらに, 花成強度を用いて, 連続低 温処理に対する断続低温処理の春化作用累積時間, な らびに，断続低温処理した場合の 1 日当たりの春化作 用時間と離春化作用時間を求めた。

花成強度は, 連続低温処理区に比べて $24^{\circ} \mathrm{C}$ 以上の 断続低温処理区で低く, 高温処理温度が高いほど, ま た, 1 日当たりの高温処理時間が長いほど低くなった。 特に, 24 および $30^{\circ} \mathrm{C}$ で 1 日当たり 6 および 8 時間の 
高温処理を行った場合に,花成強度は大きく低下した。 断続低温処理を行った場合の 1 日当たりの春化作用 時間と離春化作用時間を求めることにより, 低温遭遇 中の高温の影響を定量的に把握することができた。 $24^{\circ} \mathrm{C}$ で 1 日当たり 8 時間あるいは $30^{\circ} \mathrm{C}$ で 1 日当たり 6 時間の高温処理では低温処理で 30〜 40\% 程度が離春 化されるものと考えられた。

\section{文献}

Ito, H., Saito, T. 1961. Time and temperature factors for the flower formation in cabbage. Tohoku J. Agric. Res. 12 : 297316.

Kagawa, A., Nakamura, M. 1958. Studies on the effect of low temperature induction in radish plant. III. On the effect of high temperature to reproductive development of vernalized and unvernalized radish plant. (Japanese text with English summary) Res. Bull. Fac. Agric. Gifu Univ. 9 : 32-40.

Kitada, M., Okada, I., Fukushima, K., Matsumoto, M. 1988. The effect of high temperature after low temperature treatment on the number of differentiated leaves in Japanese radish 'Taibyo-soubutori'. (Japanese text with English summary) Bull. Toyama Veg. \& Ornam. Crops Res. Stn. 2 : 1-9.

Kodo, H., Machida, H., Kakuyama, H. 1983. Influence of temperature management in plastic tunnel and vinyl greenhouse to the flowering and the bolting of Japanese radish 'Taibyosobutori' for spring harvesting. (Japanese text) Res. Bull. Tokushima Agric. Res. 21 : 9-15.

Kodo, H., Machida, H., Bando, K. 1985. Influence of daytime temperature in early stage to the bolting of Japanese radish for spring planted in plastic tunnel. (Japanese text) Res. Bull. Tokushima Agric. Res. 22 : 6-12.

Matsubara, S., Miki, N., Murakami, K., Uchida, K. 1990. Vernalization for seed production of radish. (Japanese text with English summary) J. Jpn. Soc. Hortic. Sci. 59 : 137-142.

Moriwaki, K., Katsumata, H. 1974. Studies on prevention of bolting in umbelliferous vegetables. I. The influence of alternating temperatures on prevention of bolting in celery. (Japanese text with English summary) Res. Bull. Aichi Agric. Res. Cent. B6 : 1-5.
Moriwaki, K., Yamaguchi, H., Katsumata, H. 1975. Studies on prevention of bolting in umbelliferous vegetables. II. The influence of alternating temperatures on prevention of bolting in carrot. (Japanese text with English summary) Res. Bull. Aichi Agric. Res. Cent. B7 : 1-5.

Moriwaki, K., Yamaguchi, H., Katsumata, H. 1976. Studies on prevention of bolting in umbelliferous vegetables. III. The mechanism of the vernalizing effect or decaying the effect on celery under the alternating temperature. (Japanese text with English summary) Res. Bull. Aichi Agric. Res. Cent. B8 : 1-5.

Moriwaki, K., Yamaguchi, H. 1977. Studies on prevention of bolting of umbelliferous vegetables. IV. Prevention of bolting of carrots grown in plastic tunnel. (Japanese text with English summary) Res. Bull. Aichi Agric. Res. Cent. B9 : 1-5.

Sagwansupyakorn, C., Shinohara, Y., Suzuki, Y. 1984. Effect of day temperature on devernalization in radish. (Japanese text) Abstr. Jpn. Soc. Hortic. Sci. Autumn. 1984 Meet. 228-229.

Saito, H., Saito, T. 2001. Effects of vernalization and subsequent photoperiod on inflorescence formation in turnip. (Japanese text with English summary) J. Jpn. Soc. Hortic. Sci. 70 : 629635.

Saito, H., Saito, T. 2003. Effects of high temperature interruption during vernalization on the inflorescence formation in turnip plants. (Japanese text with English summary) J. Jpn. Soc. Hortic. Sci. 72 : 329-334.

Sato, T., Oba, S., Hasegawa, H. 1980. Studies on advancing cultivation of Japanese radish. I. Effect of high temperature during daytime on prevention of bolting in radish. (Japanese text) Abstr. Jpn. Soc. Hortic. Sci. Spring. 1980 Meet. 230-231.

Seyama, N., Takai, T. 1982. Effect of high temperature on the bolting of Japanese radish grown in the diurnal variation of temperature. (Japanese text with English summary) Bull. Veg. \& Ornam. Crops Res. Stn. Jpn. B4 : 47-60.

Suzuki, Y., Shinohara, Y., Ishii, Y. 1980. Effect of difference of night and day temperature on flower formation in Japanese radish 'Minowase'. (Japanese text) Abstr. Jpn. Soc. Hortic. Sci. Autumn. 1980 Meet. 144-145.

Watanabe, Y., Cheon, C. J., Saito, T. 2003. An approach to characterize the state of vernalization in radish plants by use of "flower formation index". (Japanese text with English summary) Environ. Control in Biol. 41, : 149-156. 